\title{
Leavening Agents for Food Industry
}

\author{
B. Neeharika ${ }^{1}$, W. Jessie Suneetha ${ }^{2 *}$, B. Anila Kumari ${ }^{1}$ and M. Tejashree ${ }^{3}$ \\ ${ }^{1}$ PJTS Agricultural University, Rajendranagar, Hyderabad - 500 030, India \\ ${ }^{2}$ Krishi Vigyan Kendra, PJTS Agricultural University, Wyra - 507165, Khammam Dt., India \\ ${ }^{3}$ Department of Agricultural Microbiology \& Bioenergy, College of Agriculture, PJTS \\ Agricultural University, Rajendranagar, Hyderabad - 500 030, India \\ *Corresponding author
}

\section{A B S T R A C T}

\section{Keywords}

Biological leavening, Chemical leavening agents, Baking, pastries, Mechanical leavening

Article Info

Accepted:

15 August 2020

Available Online:

10 September 2020
Leavening agents cause expansion of doughs and batters by the release of gases within food mixtures, producing baked products with porous structure. Leavening agents are used in food products to help create structure and texture through gas expansion because of a chemical reaction or as the nucleation seed for gas formation. Leavening can be achieved by various methods including yeast fermentation, by mechanical incorporation of air through mixing and creaming, formation of water vapour during baking and creation of carbon dioxide and/or ammonia by chemical leavens. Water vapour is important in leavening pastry, popovers, cream puffs and is assisted by air, especially in pastry. However, creation of the initial air bubbles during the mixing phase is critical before any of the other leavening agents can take effect.

\section{Introduction}

A leaven / leavening agent / raising agent is any one of a number of substances used in doughs and batters that cause foaming action (gas bubbles) to lighten and soften the mixture. An alternative or supplement to leavening agents is mechanical action for air incorporation. The leavening agents can be biological or synthetic chemicals. When a dough or batter is mixed, the starch in the flour and water in the dough form a matrix often supported further by proteins like gluten or polysaccharides like pentosans or xanthan gum. The starch gelatinizes and sets on heating leaving gas bubbles. The leavening agents increase the volume of products making them tender, lighter and enhance digestibility. They make foam out of batters as they fill air pockets or cells, contributing to the "grain" of product. They improve the crumb colour, softness (can be chewed easily), taste and smell (Vickie and Elizabeth, 2007). 


\section{Types of leavening}

The sensory properties of leavened products depend on amount of leavening gas in the mixture, rate and time of gas formation. The three principal leavening gases are:

Carbon dioxide is a major leavening agent in batters and dough. It is produced chemically by the reaction of sodium bicarbonate with an acid (wet or dry) or biologically bacteria or yeast by fermenting sugar. The amount of carbon dioxide required in a formulation is proportional to the amount of flour used.

\section{Air}

The most important function of air bubbles in leavening is that they serve as nuclei for other leavening gases, which diffuse and expand them. Air may be incorporated by creaming fat and sugar for a cake, by beating egg whites/whole eggs for sponge cake by sifting ingredients or by folding (lifting and turning) the airy egg into the mixture.

The number and size of air bubbles incorporated into the dough or batter are important for texture of the final product. A low number of large-sized air bubbles produce a final product with an open, coarse crumb grain, while a large number of smallsized bubbles produce a fine, uniform crumb grain.

If a small and large bubbles are positioned near one another in the batter or dough, the gas will diffuse from the smaller one into the larger one causing the larger one to expand and the smaller one to disappear. This phenomenon is called disproportionation or Ostwald ripening (Miller, 2016).

\section{Steam}

Steam is produced as the water in the dough or batter is heated. As the temperature increases, the vapour pressure of water increases and expands the gas bubbles in the batter or dough. Steam causes an appreciable leavening action because volume of water in a batter or dough expands 1800 times when it is converted to steam during baking (Vickie and Elizabeth, 2007). Steam leaven products are heated at fast rate like saltine crackers, extruded breakfast cereals and snacks where the temperature exceeds $100^{\circ} \mathrm{C}$ (Miller, 2016).

\section{Biological leavening agents}

Leavening may be the result of fermentation, the biological process where microorganisms like bacteria or yeast metabolize ferment organic matter in food.

\section{Bacteria}

Lactobacillus sanfrancisco is responsible along with a nonbakers' yeast Saccharomyces exiguus for forming sourdough bread. The bacteria degrade maltose, yielding acetic, lactic acids and producing $\mathrm{CO}_{2}$ (Vickie and Elizabeth, 2007).

\section{Yeast}

The most common strain of yeast used in bread making is Saccharomyces cerevisiae. Yeast releases zymase to metabolize fermentable sugars yielding ethanol and $\mathrm{CO}_{2}$. Most of the alcohol is volatized in baking andCO $\mathrm{C}_{2}$ provides leavening. It gives distinct aroma and flavour to product.

\section{Commercial applications}

\section{Brewing}

Saccharomyces cerevisiae used for brewing beer called top-fermenting or top-cropping yeast because during fermentation process its hydrophobic surface causes the flocs to adhere to $\mathrm{CO}_{2}$ and rise to the top of the 
fermentation vessel. Top-fermenting yeasts are fermented at higher temperatures than lager yeast Saccharomyces pastorianus resulting in beers with different flavour. "Fruity esters" may be formed if the temperature of the beverage fluctuates during fermentation process.

\section{Baking}

Baker yeast ferments monosaccharides, disaccharides, trisaccharide and tetrasacharides but cannot fermentlactose (milk sugar).In bread making, yeasts raise the dough improving palatability by producing alcohol, aldehydes, ketones and acids that contribute to its aroma and taste(Miller, 2016).

\section{Factors affecting reaction of yeast}

Sugar: Sugar is food for yeast that helps yeast to raise the dough. Ideally sugar concentration should not exceed $10.0 \%$ of flour in dough. If sugar is used above this level, yeast cells are destroyed due to high osmotic pressure exerted by sugar (Elizabeth and Vickie, 2003).

Salt: Salt controls the activity of yeast during fermentation with tightening action on flour protein. It should be dissolved completely before use as powdered salt or too much salt inhibits yeast activity.

Water: Lukewarm water provides favourable temperature for activity of yeast whereas higher temperature of water can kill yeast resulting in no leavening.

Proving chamber: Proving chamber is a cupboard where temperature is set for yeast. Yeast grows best at $25-33^{\circ} \mathrm{C}$ and slows down below $10^{\circ} \mathrm{C}$.

Acidic environment: Yeast grows and ferment best in acidic environment tolerating acidities as low as $\mathrm{pH} 2$.

Spices: Spices such as cardamom, cinnamon, ginger and nutmeg greatly increase yeast activity. The use of dry mustard has the opposite effect and decreases yeast activity (Vickie and Elizabeth, 2007).

\section{Types of yeast}

Baker's yeast is available in different forms and the main difference being the moisture content (Linda and Stanley, 2007). Dry yeast forms are good choices for longer-term storage without significant loss of viability. The different types are cream, compressed, active dry, instant, rapid rise and deactivated yeasts (Peter, 2001).

\section{Methods of using yeast}

In general, a yeast flavour in the baked bread is not noticeable when the bakers' percentage of added yeast is less than $2.5 \%$ (Stanley, 2003).

Straight dough method: $1.0 \%$ of yeast is used and all the ingredients are incorporated in one long process of mixing and kneading. Dough is allowed to rise four times.

No time dough method: About 2.0-6.0\% of yeast is used when in a hurry. The bread may have a strong yeast flavour due to more quantity of yeast present in the dough.

\section{Chemical leavens}

Chemical leavens are mixtures or compounds that release gases when they react with each other, with moisture or heat. Most of them are based on a combination of acid (usually a low molecular weight organic acid) and a salt of bicarbonate $\left(\mathrm{HCO}^{3-}\right)$. After they act, these compounds leave behind a chemical salt. Chemical leavens are used in quick breads, cakes, cookies and numerous other 
applications where a long biological fermentation is impractical or undesirable (Harold, 2004; Linda, 2017).

\section{Baking soda}

It chemically produces $\mathrm{CO}_{2}$ when heated as follows:

$$
\mathrm{NaHCO}_{3}(\mathrm{~s}) \underset{\Delta}{\longrightarrow} \mathrm{Na}_{2} \mathrm{CO}_{3}(\mathrm{~s})+\mathrm{H}_{2} \mathrm{O}(\mathrm{g})+\mathrm{CO}_{2}(\mathrm{~g})
$$

It also liberates the same gas when mixed with an acid, either hot or cold. When used alone, baking soda reacts quickly with heat and $\mathrm{CO}_{2}$ may escape from raw batter before it is able to leaven. It even reacts with the shortening and a residual flavour is felt besides causing unpleasant taste, brown colour and alkaline odour. Therefore, baking soda must be combined with suitable quantity of acid so that neutral residue is formed.

If a batter or dough is made too alkaline with addition of baking soda, sodium carbonate is produced in food product and forms soapy flavour, spotty brown colour and yellowing of flavonoid pigment. This may occur in buttermilk (soda-acid) biscuits if soda is present in greater amounts than the acid with which it reacts. In contrast to alkalinity, the $\mathrm{pH}$ is too acidic, baked products such as biscuits exhibit whitening in colour (Vickie and Elizabeth, 2007).

\section{Baking powder}

Baking powder contains sodium bicarbonate, dry acid and inert corn starch filler. The starch filler keeps the soda and acid from reacting with each other prematurely and standardizes the weight in baking powder canister (Brodie and Godber, 2007; Sarah, 2018). Commercial baking powder yield at least $12.0 \%$ available $\mathrm{CO}_{2}$ gas by weight and home-use powders yield $14.0 \% \mathrm{CO}_{2}$.

When combined with water, the sodium bicarbonate and acid salts react to produce gaseous carbon dioxide. The acid-base reaction can be generically represented as shown:

$\mathrm{NaHCO}_{3}+\mathrm{H}^{+} \rightarrow \mathrm{Na}^{+}+\mathrm{CO}_{2}+\mathrm{H}_{2} \mathrm{O}$

A typical formulation by weight contains about $30 \%$ sodium bicarbonate, 5-12\% monocalcium phosphate and $21-26 \%$ sodium aluminium sulphate (Brodie and Godber, 2007).

\section{Classification}

Baking powders are classified in several manners. One method is according to the type of acid component. The acids differ in strength, and thus each determines the rate of $\mathrm{CO}_{2}$ release. While in the past, tartrate and phosphate were used as the dry acid, now consumers use the more common SAS phosphate (sodium aluminium sulphate phosphate).

Baking powders also are also classified according to their action rate or how quickly they react with water and heat to form $\mathrm{CO}_{2}$. The time and rate of gas evolution from baking powder can be regulated by the selection of different baking acids that react faster or slower with sodium bicarbonate. When the chemical reactions in baking powders involve only one acid, they are known as "single-acting".

A fast-acting acid reacts in a wet mixture with baking soda at room temperature and releases most of its $\mathrm{CO}_{2}$ gas during bench operation and very little during baking. A slow-acting acid does not release much of gas during bench operation but is released when it comes in contact with heat (Brodie and Godber, 2007).

When the chemical reactions in baking powders involve both fast- and slow-acting acids, they are known as "double-acting". They are most widely used and available to 
consumers today. Double-acting baking powders work in two phases.

They release part of gas during bench operation (while mixing), increasing fluidity of cake batter. The remaining gas is released during baking, which gives volume to the end product, e.g. SAS phosphate (Corriher, 2008).

\section{Neutralizing value (NV)}

$\mathrm{NV}$ is the term used to describe the amount of leavening acid needed to react completely

\begin{tabular}{|l|c|l|c|}
\hline \multicolumn{1}{|c|}{ Leavening acid } & NV & \multicolumn{1}{c|}{ Leavening acid } & NV \\
\hline $\begin{array}{l}\text { Monocalcium phosphate } \\
\text { monohydrate }\end{array}$ & 80 & Dimagnesium phosphate & 40 \\
\hline Anhydrous monocalcium phosphate & 83 & Sodium aluminium sulphate & 104 \\
\hline Sodium acid pyrophosphate & 74 & Cream of tartar & 45 \\
\hline Sodium aluminium phosphate & 100 & Glucono- $\delta$-lactone & 45 \\
\hline Dicalcium phosphate dihydrate & 33 & & \\
\hline
\end{tabular}

(Vetter, 2003)

\section{Ammonium bicarbonate}

Ammonium bicarbonate decompose during baking and release ammonia and carbon dioxide without reacting with leavening acid. Unlike sodium bicarbonate, ammonium bicarbonate leaves no residue when it decomposes by heat. Therefore, it has no effect on $\mathrm{pH}$ of baked product and hence does not require a leavening acid. Because ammonia gas dissolves in water, if there is more than about $5.0 \%$ moisture in the baked product, it imparts an ammonic flavour to product and making it inedible.

For this reason, it is used only in lowmoisture products such as crackers and dry cookies. Further, ammonia bicarbonate does not produce salts, which have an adverse effect on dough rheology

$$
\underset{\text { (ammonium bicarbonate) }}{\mathrm{NH}_{4} \mathrm{HCO}_{3}} \stackrel{\text { heat }}{\rightarrow} \underset{\text { (ammonia) }}{\mathrm{NH}_{3}}+\underset{\text { (carbon dioxide) }}{\mathrm{CO}_{2}}+\underset{\text { (water) }}{\mathrm{H}_{2} \mathrm{O}}
$$

(Vetter, 2003) with the amount of baking soda used in formulating a bakery product. If all of the soda reacts with the leavening acid, the finished product should be close to neutral in $\mathrm{pH}$, which is desired in most products.

Larger amounts of leavening acids with low $\mathrm{NVs}$ are required for a given amount of soda than for those leavening acids with higher NVs. The NVs for commonly used leavening acids are listed below:

\section{Potassium bicarbonate}

Potassium bicarbonate can be used as a substitute for sodium bicarbonate to lower the sodium content of the finished product. It is soluble in water and partly decomposes upon heating to give partial release of available $\mathrm{CO}_{2}$, thus requiring a leavening acid in order to yield complete release of $\mathrm{CO}_{2}$. Potassium bicarbonate is seldom used because it has a bitter aftertaste and is highly hygroscopic, making it difficult to store:

$\underset{\text { (potassium bicarbonate) }}{\mathrm{KHCO}_{3}}+\underset{\text { (acid salt) }}{\mathrm{H}^{+}} \rightarrow \underset{\text { (neutral salt) }}{\mathrm{K}^{+}}+\underset{\text { (carbon dioxide) }}{\mathrm{CO}_{2}}+\underset{\text { (water) }}{\mathrm{H}_{2} \mathrm{O}}$

(Miller, 2016)

\section{Mechanical leavening}

\section{Creaming}

It is the process of beating sugar crystals and solid fat (typically butter) together in a mixer. This integrates tiny air bubbles into the mixture, since the sugar crystals physically 
cut through the structure of fat, which expand under the action of heat and in the process give volume to the products.

Creamed mixtures are usually further leavened by a chemical leaven like baking soda before heating. This process is often used in preparation of cookies.

\section{Whisking or whipping}

Using a whisk on certain liquids, notably cream or egg whites can also create foams through mechanical action. This method employed is in the making of sponge cakes, where an egg protein matrix produced by vigorous whipping provides almost all the structure of the finished product.

In conclusion the leavening agents are used to achieve a light and crunchy texture and to increase the volume and porosity of baked foods like cakes, breads and cookies. They include air, steam, yeast, baking powder, baking soda, etc.

Their characteristics and potential applications in food industry were described. The batter and dough products are leavened by water vapour, air, carbon dioxide and sometimes ammonia. The gases are distributed as small bubbles in batters and doughs and the fineness of their dispersion is responsible for the grain of the baked products.

\section{References}

Brodie, J and Godber, J. 2007. Bakery Processes, Chemical Leavening Agents. Kirk-Othmer Encyclopedia of Chemical Technology.1-14.

Corriher, S.O. 2008. BakeWise: The Hows and Whys of Successful Baking with Over 200 Magnificent Recipes. Scribner.

Elizabeth, C.W and Vickie, V. 2003. Essentials of food science. Kluwer Academic/Plenum Publishers,New York, USA. p. 323.

Harold, G. 2004. On Food and Cooking. ScribnerSimon \& Schuster. p. 533.

Linda, C. 2017. Baking powder wars: the cutthroat food fight that revolutionized cooking. University of Illinois Press, Urbana, Illinois. pp. 45, 70-74.

Linda, Y and Stanley, P.C. 2007. Technology of Breadmaking. Springer, Berlin. p. 79.

Miller, R. 2016. Leavening agents. In Caballero, B., Finglas, B.M and Toldra, F. Encyclopedia of Food and Health. Elsevier, USA. 1(A): 523-528.

Peter, R. 2001. The bread baker's apprentice: mastering the art of extraordinary bread. Ten Speed Press, Berkeley. p. 61.

Sarah, R. 2018. Baking up a Storm: When crime and politics influenced American baking habits. Distillations. 4 (3): 46-47.

Stanley, P.C. 2003. Bread making: improving quality. CRC Press, Boca Raton.

Vetter, J.L. 2003. Leavening agents. In Caballero, B. (ed.). Encyclopedia of Food Sciences and Nutrition. $2^{\text {nd }}$ ed. Elsevier Science. pp 34853490.

Vickie, A.V and Elizabeth, W.C. 2017. Baked Products: Batters and Dough. Essentials of food science. $3^{\text {rd }}$ ed. Springer, New York, USA. pp. 357-369.

Wayne, G. 2008. Professional baking. John Wiley, New York.

\section{How to cite this article:}

Neeharika, B., W. Jessie Suneetha, B. Anila Kumari and Tejashree, M. 2020. Leavening Agents for Food Industry. Int.J.Curr.Microbiol.App.Sci. 9(09): 1812-1817.

doi: https://doi.org/10.20546/ijcmas.2020.909.227 